African Crop Science Journal by African Crop Science Society is licensed under a Creative Commons Attribution 3.0 Uganda License. Based on a work at www.ajol.info/ and www.bioline.org.br/cs DOI: https://dx.doi.org/10.4314/acsj.v27i3.10

\title{
HOST RANGE AND BANANA CULTIVARS' SUSCEPTIBILITY TO Xanthomonas campestris pv. musacearum IN RWANDA
}

\author{
F. UWAMAHORO ${ }^{1,2}$, C. BUCAGU ${ }^{3}$, A. BERLIN ${ }^{1}$, H. BYLUND ${ }^{4}$ and J. YUEN ${ }^{1}$ \\ ${ }^{1}$ Department of Forest Mycology and Plant Pathology, Swedish University of Agricultural \\ Sciences, P. O. Box 7026, SE-750 07 Uppsala, Sweden \\ ${ }^{2}$ Department of Crop Science, College of Agriculture Animal Sciences and Veterinary Medicine, \\ University of Rwanda, P. O. Box 210, Musanze, Rwanda \\ ${ }^{3}$ Rwanda Agriculture Board, Ministry of Agriculture and Animal Resources, P. O. Box 5016, \\ Kigali, Rwanda \\ ${ }^{4}$ Department of Ecology, Swedish University of A gricultural Sciences, P. O. Box 7044, SE-750 07 , \\ Uppsala, Sweden \\ Corresponding author: florence.uwamahoro@slu.se,umflora@gmail.com
}

(Received 28 February 2019; accepted 31 July 2019)

\begin{abstract}
Xanthomonas campestris pv. musacearum $(\mathrm{Xcm})$, a bacterium causing banana xanthomonas wilt (BXW) disease, is widely spread in the East and Central Africa and infects all cultivated bananas. The first objective of this study was to identify plant species produced in banana cropping systems of Rwanda that may act as host of $X \mathrm{~cm}$, and to evaluate the susceptibility of different banana cultivars in Rwanda. Eighteen plant species including banana, banana-intercrop species and plant species closely related to banana were used to study the host range of $\mathrm{Xcm}$. Similarly, five banana cultivars (Fhia-17, Fhia-25, Injagi, Mpologoma and Nkazikamwa) were used to assess their susceptibility level to Xcm. Tested plant species and banana cultivars were inoculated with $\mathrm{Xcm}$ isolate in a controlled environment. Only banana and its relatives (enset, blood banana, achira, African arrowroot, and Indian shot) developed xanthomonas wilt symptoms. Time to first symptoms expression and to complete wilting varied significantly $(\mathrm{P}<0.0001)$ between susceptible plant species. Longer survival times $(\mathrm{P}<0.0001)$ were observed in wild (blood) banana, Canna species and enset compared to cultivated banana. Since these susceptible plant species could host the bacteria, they should be avoided in farms or gardens neighbouring banana fields. All the five banana cultivars tested were susceptible to $\mathrm{Xcm}$. Among the cultivars, Mpologoma was first to express disease symptoms and to wilt completely; while the longest incubation period and time to complete wilting were recorded in cultivar Fhia-17. Due to the broad host range and high susceptibility of banana cultivars to $\mathrm{Xcm}$, information about how to limit the spread of the bacteria is crucial for disease control.
\end{abstract}

Key Words: Disease progress, Musa spp., Xanthomonas wilt 
Xanthomonas campestris pv. musacearum $(\mathrm{Xcm})$, une bactérie responsable du flétrissement xanthomonas de bananier, est largement répandue en Afrique Orientale et Centrale et infecte tous les bananiers cultivés. Le premier objectif de cette étude était d'identifier les espèces végétales produites dans les systèmes de culture de la banane au Rwanda pouvant servir d'hôtes à Xcm. Le deuxième objectif était d'évaluer la sensibilité de différents variétés de bananiers au Rwanda. Dix-huit espèces de plantes, y compris la banane, les cultures intercalaires de bananier, les cultures aux champs voisins des bananiers et les espèces de même famille que les bananiers ont été utilisées pour étudier la gamme d'hôtes de Xcm. De même, cinq variétés de bananiers (Fhia-17, Fhia-25, Injagi, Mpologoma et Nkazikamwa) ont été utilisées pour vérifier leur niveau de sensibilité au $\mathrm{Xcm}$. Les espèces de plantes et les variétés de bananiers testées, ont été inoculées avec un isolat de $\mathrm{Xcm}$ dans un environnement contrôlé. Seule la banane et ses proches (ensète, banane sauvage, et espèces de Canna) ont présenté des symptômes du flétrissement xanthomonas. Le nombre de jours jusqu' à l'apparition des premiers symptômes et au flétrissement complet a varié de manière significative $(\mathrm{P}<0,0001)$ entre les espèces de plantes sensibles à la bactérie. Temps de survie prolongées $(\mathrm{P}<0,0001)$ a été observés chez le bananier sauvage, espèces de Canna et ensète par rapport au bananier cultivé. Étant donné que ces espèces végétales sensibles pourraient héberger des bactéries, il convient de les éviter dans les exploitations agricoles ou jardins situés à proximité des bananiers. Les cinq variétés de bananiers testés étaient sensibles à $\mathrm{Xcm}$. Parmi les variétés, Mpologoma a été le premier à exprimer les symptômes de la maladie et à flétrir complètement, alors que la période d'incubation et le temps pour flétrir complétement étaient plus longs chez la variété Fhia-17. En raison du large éventail d'hôtes et de la grande sensibilité des variétés de bananiers au Xcm, il est crucial de disposer d'informations sur la manière de limiter la propagation de la bactérie pour lutter contre la maladie.

Mots Clés: Progression de la maladie; Musa spp.; flétrissement Xanthomonas

\section{INTRODUCTION}

The bacterium, Xanthomonas campestris pv. musacearum $(X \mathrm{~cm})$, is the causal organism of banana xanthomonas wilt (BXW) disease, a major threat to banana production in the East and Central Africa (Tripathi et al., 2009). First reports of $X \mathrm{~cm}$ came from Ethiopia on enset (Ensete ventricosum) and banana (Musa spp.) in 1964 and 1968, respectively (Yirgou and Bradbury, 1968; Yirgou and Bradbury, 1974). Three decades later, the pathogen and disease suddenly emerged and spread throughout the Great Lakes region, starting from central Uganda in 2001 (Carter et al., 2010).

The symptoms of $X \mathrm{~cm}$ on banana include progressive yellowing and wilting of leaves, starting from the youngest leaf, withering of male buds, premature ripening of the fruit and yellow bacterial ooze observed in about 15 minutes after the pseudostem is cut, confirming the presence of the disease (Tinzaara et al., 2006). If uncontrolled, the disease reduces incomes of banana farmers, increases food prices and threatens food security (Nkuba et al., 2015).

Apart from the cultivated enset and banana, $X \mathrm{~cm}$ has been found to infect several other hosts including Musa zebrina, Musa ornata and Canna indica (Ssekiwoko et al., 2006a); maize, sorghum and sugarcane (Aritua et al., 2008; Karamura et al., 2015); wild enset, wild and cultivated sorghum, Canna spp., maize and sugarcane (Chala et al., 2016). Aritua et al. (2008) showed the ability of $X \mathrm{~cm}$ to cause disease in maize. However, Karamura et al. (2015) could not observe the symptoms in maize but could re-isolate the bacterium $\mathrm{Xcm}$ from inoculated but healthy looking maize, thereby confirming its ability to harbour the bacterium. 
All banana cultivars in the East and Central Africa, including highland cooking and brewing cultivars (AAA-EA), exotic brewing, dessert and roasting types $(\mathrm{AB}, \mathrm{AAA}, \mathrm{AAB}$, $\mathrm{ABB}$ ) and hybrid cultivars are susceptible to Xcm (Ssekiwoko et al., 2006b). However, Tripathi and Tripathi (2009) demonstrated differences in level of susceptibility between banana cultivars in Uganda, where some ABB cultivars like 'Pisang Awak' demonstrated high susceptibility to disease; whereas the East African Highland banana cultivar Nakitembe (AAA-EA) were less susceptible to the disease. In addition, transgenic banana cultivars developed using transgenes encoding for plant ferredoxin-like protein ( $p f l p)$ and hypersensitive response assisting protein (hrap) isolated from sweet pepper (C. апnиит), have proven to be resistant, over three cropping cycles (Tripathi et al., 2014). These cultivars are currently not approved for marketing and are, therefore, not available for farmers (Blomme et al., 2017).

In Rwanda, Xcm was first reported in 2005 on banana (Reeder et al., 2007). From then, there have been no reports of the bacterium or symptoms observed on any other host in the country (Nakato et al., 2018). Since previous studies indicate the possibility of $X \mathrm{~cm}$ to infect other hosts elsewhere (Ssekiwoko et al., 2006a; Aritua et al., 2008; Karamura et al., 2015; Chala et al., 2016; Ocimati et al., 2018), there is a need to identify potential hosts among the crops and plants grown in or around banana fields in order to limit the spread of the bacteria. In addition, all the cultivars available in Rwanda are thought to be susceptible to $\mathrm{Xcm}$; however, the level of susceptibility to the bacterium may differ from one cultivar to the other (Tripathi and Tripathi, 2009). This study was designed to assess the ability of $X \mathrm{~cm}$ to infect crops intercropped with banana, crops grown in neighbouring fields to banana and cultivated banana relatives in Rwanda; and to evaluate the susceptibility level of different banana cultivars produced in Rwanda.

\section{MATERIALS AND METHODS}

Isolation and pathogenicity test of $X$. campestris pv. musacearum. The pathogen associated with BXW was isolated from infected banana, according to the method described by Ssekiwoko et al. (2006a). To avoid introduction of a new isolates, the infected banana samples were collected from the area where the inoculations experiments were to be carried out (Nyakinama, Musanze $1^{\circ} 33^{\prime} 16.2^{\prime \prime S} 29^{\circ} 38^{\prime} 26.2^{\prime \prime E}$ ).

A piece of the central pseudostem $(20 \mathrm{~cm}$ long) was cut and surface sterilised using 5\% sodium hypochlorite. Small pieces (approx. 5 $\mathrm{cm}$ long) were cut from the pith and suspended in $1 \mathrm{ml}$ of sterile distilled water for 5 minutes, to allow bacteria to ooze out. A loopful of this bacterial suspension was streaked on Yeast Peptone Glucose Agar (YPGA) plates, under sterile conditions. The plates were then incubated for 24 to 48 hours at $28{ }^{\circ} \mathrm{C}$, the optimum temperature for Xanthomonas spp. (Karamura et al., 2015), to allow bacterial growth in the medium. Single colonies of the bacteria were picked and streaked on plates containing yeast dextrose chalk agar (YDCA) for purification. The yellow mucoid and highly convex characteristic culture of $X \mathrm{~cm}$, helped to identify the bacteria (Ssekiwoko et al., 2006a). Fresh culture of Xcm (48 hours old) was harvested into sterile distilled water and was adjusted to a concentration of $10^{8}$ colony forming units $\left(\mathrm{cfu} \mathrm{ml}^{-1}\right)$ by the drop plate count technique (Herigstad et al., 2001).

To confirm the virulence of the isolated bacteria, a $1 \mathrm{ml}$ bacterial suspension containing $10^{8} \mathrm{cfu} \mathrm{ml}^{-1}$ was inoculated to 6 weeks old banana plantlets (cultivar 'Injagi'), using a 2 $\mathrm{ml}$ hypodermic syringe. Control plantlets were inoculated with sterile distilled water. The plantlets were monitored daily for symptom expression. After 12 days, the first symptoms appeared, showing that the bacterial isolate under study was virulent. Hence, it was used for testing the host range of $X \mathrm{~cm}$, and for screening banana cultivars for susceptibility 
to the bacterium. Fresh inoculum of $X \mathrm{~cm}$ was used for all the experiments, in order to ensure high virulence potential of the pathogen. The inoculation experiments were conducted in a screen house at Nyakinama (1 33 '16.2"S $\left.29^{\circ} 38^{\prime} 26.2^{\prime \prime E}\right)$, a banana growing area in Musanze, Rwanda. Bacterial presence was confirmed from inoculated plant species by ooze test (Blomme et al., 2017).

Host range of $X$. campestris pv. musacearum. Eighteen plant species including banana, banana intercrops, crops that are grown in fields neighbouring banana fields, and plants closely related to banana were used to study the host range of $\mathrm{Xcm}$ (Table 1). Banana cultivar 'Injagi' was used as a positive control. The seeds and planting materials of the test plants, were sourced from different places, including seed companies, research institutions, local flower companies, and from farmers in Musanze (Table 1).

Planting dates for these plant species varied, depending on test plants' needs. All the seeds, shoots and plantlets were planted in steam sterilised soil. The plant species grown from small seeds in nursery (Table 1) were planted first. A week later, other seed crops, and planting materials of crops vegetatively propagated were planted (Table 1). The transplantation was conducted two weeks later in experimental pots, for plants obtained at plantlet stage (African arrowroot, achira, banana, blood banana, enset, Indian shot, and potato), and the plantlets from the nursery. Only one plantlet per pot per species was allowed to establish prior to inoculation.

All the test plants were inoculated with $\mathrm{Xcm}$ on the same day, one month after transplantation. For each plant species, a total of 15 plantlets were used, 12 were inoculated with the bacterium and 3 were inoculated with water to serve as negative control using a hypodermic syringe. The plants were inspected daily to record days to first symptom appearance. Following first symptoms expression, plants were assessed on a weekly basis for 8 weeks to assess the disease incidence and severity. Days to complete wilting were also monitored daily and recorded for each symptomatic plant.

Wilt incidence was calculated as the percentage of wilted plants per total number of plants inoculated. Percent severity was calculated by transforming the 1-5 severity scale (Horita and Tsuchiya, 2001) into percent wilting; where scale $1=0 \%$ no symptom, $2=$ $20 \%$ one to two leaves wilted, $3=50 \%$ half of the leaves wilted, $4=75 \%$ almost all the leaves wilted and $5=100 \%$ the whole plant died (Uwamahoro et al., 2018).

Screening banana cultivars for susceptibility to $X$. campestris pv. musacearum. Five banana cultivars (Fhia17, Fhia-25, Injagi, Nkazikamwa and Mpologoma) were obtained from the tissue culture laboratory of Rwanda Agriculture Board (RAB) Rubona, after one month of hardening in the greenhouse. The cultivars' genetic groups and uses are presented in Table 2 (Crichton et al., 2014; Karamura et al., 2012). The choice of cultivars was based on their availability in the tissue culture laboratory. This laboratory produces disease free suckers to be distributed to seed multipliers, who in turn produce healthy planting materials for farmers.

Ten plants of each cultivar were inoculated with $1 \mathrm{ml}$ of the bacterial inoculum $\left(10^{8} \mathrm{cfu}\right.$ $\mathrm{ml}^{-1}$ ), using a sterile hypodermic syringe. This experiment was replicated 4 times. Eight control plants for each cultivar were inoculated with $1 \mathrm{ml}$ sterile distilled water. The plants were inspected daily to record first symptom appearance. Following first appearance, plants were assessed on a weekly basis during 8 weeks to check for the disease incidence and severity. Percent wilt incidence and severity were calculated as described above. Signs of complete wilting were monitored daily, and days to complete wilting recorded. 
TABLE 1. Plant species used in the host range experiment, their common and scientific names, and sources of planting material

\begin{tabular}{|c|c|c|c|c|}
\hline Plants category & Common name & Scientific name & Varieties & Source \\
\hline \multirow[t]{9}{*}{ Banana intercrops } & Amaranth & Amaranthus spp. & NA & Agrotech \\
\hline & Cassava & Manihot esculenta & Local & Local farmers \\
\hline & Common beans & Phaseolus vulgaris & Local bush bean & Local market \\
\hline & Groundnuts & Arachis hypogaea & Local & Local market \\
\hline & Potato & Solanum tuberosum & Kirundo & RAB Musanze \\
\hline & Pumpkins & Cucurbita pepo & Anderina & Agrotech \\
\hline & Sweet pepper & Capsicum & California Wonder & Balton Rwanda \\
\hline & Taro & Colocasia esculenta & Local & Local farmers \\
\hline & Tomato & Solanum lycopersicum & Sugar baby & Balton Rwanda \\
\hline \multirow[t]{3}{*}{ Crops in neighbouring fields to banana } & Maize & Zea mays & Pool 19A(Tamira) & Seed company \\
\hline & Sorghum & Sorghum bicolor & Serena & Seed company \\
\hline & Wheat & Triticum aestivum & Stallion & RAB Musanze \\
\hline \multirow[t]{5}{*}{ Ornamental relatives of banana } & Achira & Canna edulis & NA & Flower Company \\
\hline & African arrowroot & Canna indica & NA & Flower Company \\
\hline & Blood/Wild banana & Musa acuminata ssp. zebrina & NA & Flower Company \\
\hline & Enset & Ensete ventricosum & NA & Flower Company \\
\hline & Indian shot & Canna pretoria & NA & Flower Company \\
\hline Positive control & Banana & Musa spp. & Injagi & RAB Rubona \\
\hline
\end{tabular}


TABLE 2. Banana cultivars used in the experiment, their genetic groups and uses

\begin{tabular}{lll}
\hline Cultivar names & Genetic group & Uses \\
\hline Fhia-17 & AAAA & Dessert banana \\
Fhia-25 & AABB & Brewing (Beer) banana \\
Injagi & AAA & East African Highland Cooking banana \\
Mpologoma & AAA & East African Highland Cooking banana \\
Nkazikamwa/Mbwazirume & AAA & East African Highland Cooking banana \\
\hline
\end{tabular}

Source: Tripathi and Tripathi (2009)

Ooze test and sample preparations. At 8 weeks after inoculation, samples were collected from each of the plant species for checking bacterial streaming (ooze test) and for squeezing on Whatman ${ }^{\mathrm{TM}} \mathrm{FTA}^{\mathrm{TM}}$ cards (GE Healthcare) for PCR tests. The ooze test was carried out by suspending $5 \mathrm{~cm}$ piece of the plants' stems in a glass of water for 10 to 20 minutes and observed for bacterial streaming in the water.

For each sample, genomic DNA was extracted from the FTA ${ }^{\mathrm{TM}}$ cards, using Chelex 100 resin, following the manufacturer's instructions (GE Healthcare, 2010). The resulting DNA was quantified using a NanoDrop Spectrophotometer (Thermo Fisher Scientific, Waltham, MA, USA), and diluted to $3 \mathrm{ng}$ per $\mu$ l for use in PCR to confirm $\mathrm{Xcm}$ presence in the inoculated plant species.

To identify the bacterium, three primers previously shown to amplify $X$. campestris $\mathrm{pv}$. musacearum were used. These include BXW1 (5' GTCGTTGGCACCAT GCTCA 3') and BXW-3 (5' TCCGACCGATA CGGCT 3') resulting in a $214 \mathrm{bp}$ size fragment (Lewis Ivey et al., 2010); NZ085-F3 (5' CGTGCCATGTA TGCGCTGAT 3') and NZ085-R3 (5' GAGCG GCATAGT GCGACAGA 3') amplifying a 349bp size fragment; and GspDm-F2 (5' GCGGTTACAACACCGTTCAAT 3') and GspDm-R3 (5' AGGTGGAGTTGATCGG AATG 3') amplifying a 256 bp fragment (Adriko et al., 2012; Ocimati et al., 2018). The PCR amplifications were performed separately in $20 \mu \mathrm{l}$ volume reactions containing
30 ng DNA sample, $0.2 \mathrm{mM}$ of each of the forward and reverse primers, $0.2 \mathrm{mM} \mathrm{dNTP}$ mix, 0.5 U DreamTaq DNA polymerase (Thermo Scientific) and corresponding $1 \mathrm{x}$ DreamTaq buffer, extra $\mathrm{MgCl}_{2}$ was added to a final concentration of $3.5 \mathrm{mM} \mathrm{MgCl}$. Water was used as a negative control. The PCR was performed in a 2720 Thermo cycler (Applied Biosystems ${ }^{\mathrm{TM}}$ ), using the following procedure: an initial denaturation at $95{ }^{\circ} \mathrm{C}$ for $3 \mathrm{~min}$; followed by 32 cycles of $20 \mathrm{~s}$ at $95{ }^{\circ} \mathrm{C}$, annealing of $15 \mathrm{~s}$ at $64{ }^{\circ} \mathrm{C}$, elongation for $13 \mathrm{~s}$ at $72{ }^{\circ} \mathrm{C}$; and then a $3 \mathrm{~min}$ final extension at $72{ }^{\circ} \mathrm{C}$ (Adriko et al., 2012). PCR products (6 $\mu 1)$ were separated by horizontal gel electrophoresis, in $1.5 \%$ agarose in $0.5 \times \mathrm{SB}$ buffer at $140 \mathrm{~V}$ for $40 \mathrm{~min}$. Gels were stained with Nancy-250 (1 ml per $50 \mathrm{ml}$ gel) and DNA was visualised using Quantity One Gel Doc XR (BioRad).

Statistical analyses. The average percent wilt incidence and severity data of different hosts and banana cultivars were used to calculate the area under disease progress curve (AUDPC) in R statistical software package Agricolae (De Mendiburu, 2015), using the formula developed by Madden et al. (2007). Differences in days to first symptom expression and to complete wilting among test plants were tested, using Kaplan-Meier (KM) curves and Cox proportional hazard in the $\mathrm{R}$ package OIsurv (Rich et al., 2010; Diez, 2013; Nunes Nesi et al., 2013). Survival studies, using KM curves have been widely used in 
medical science, dealing with differing survival times or times to event (Rich et al., 2010), but rarely used in plant pathology (Nunes Nesi et al., 2013). The steps in KM curves indicate the instants of time in which events occur (Rich et al., 2010; Nunes Nesi et al., 2013). This type of survival analysis is applied when the time until the occurrence of an event is the object of interest. Here, we used the days to symptoms expression and days to complete wilting as survival times or times to events. Test plant species without disease symptoms by the last day of the observation period, were analysed as censored (Copes and Thomson, 2008; Esker et al., 2006; Setti et al., 2010).

\section{RESULTS}

Host range of $X$. campestris pv. musacearum. Of the 18 plant species inoculated with the $\mathrm{Xcm}$ isolate, only six viz. banana, blood banana, African arrow root, achira, Indian shot and enset developed symptoms of xanthomonas wilt (Fig. 1). The other species remained healthy during experimental period. The symptoms on banana and banana relatives were progressive yellowing of leaves that led to complete wilting of these plants (Fig. 1). The AUDPC for BXW incidence and severity varied between the symptomatic hosts. The lowest AUDPC was observed in African arrowroot (2800 and 952 respectively); whereas the highest (3962 and 2324 , respectively) was observed in banana (Table 3).

The time to expression of xanthomonas wilt symptoms significantly varied between susceptible hosts $(\mathrm{LRT}=58.6, \mathrm{df}=5, \mathrm{P}<$ 0.0001) (Fig. 2a). The first symptoms appeared on a banana plantlet at the 12th day after inoculation (DAI); whereas the last to express the symptoms was African arrowroot (C. indica) at the 37th DAI. Banana, enset and Indian shot (Canna pretoria) were not significantly different in time to symptoms expression $(\mathrm{P}>0.05)$. However, time to first symptoms was significantly longer in wild (blood) banana, African arrowroot (Canna indica) and achira (Canna edulis) $(\mathrm{P}<0.0001)$ than for cultivated banana (Fig. 2a).

The number of days until complete wilting also varied significantly (LRT $=96.2, \mathrm{df}=5$, $\mathrm{P}<0.0001$ ) between the susceptible hosts (Fig. 2b). Banana and enset wilted completely earlier than other hosts; whereas wild banana and all the Canna species survived longer. Compared to cultivated banana, wild banana showed significantly longer survival time $(\mathrm{P}<0.0001)$. All the inoculated susceptible plants eventually wilted completely, but at slightly different time points (Fig. 2b). However, Canna species sprouted a few days after the inoculated mother plant was completely wilted (Fig. 3).

Screening cultivars for susceptibility. All the banana cultivars inoculated with $\mathrm{Xcm}$ showed symptoms of the disease, and they wilted completely at relatively different time points (Fig. 4). Cultivar Mpologoma was the first to express disease symptoms and to completely wilt, while the incubation period and time to complete wilting were the longest in Fhia-17 (Fig. 4).

The AUDPC for incidence and severity of BXW varied between cultivars, though 100\% of the inoculated plants expressed disease symptoms earlier than 6 weeks after inoculation for all tested cultivars. The lowest value for AUDPC was observed in cultivar Fhia-17, and the highest in the cultivar Mpologoma (Table 5). High values of AUDPC correspond to more susceptible cultivars, while lower values indicate the less susceptible cultivars.

Results of Ooze test and PCR. An ooze test was performed to check if test plant species harboured $\mathrm{Xcm}$. Bacterial streaming was only observed on samples from plant species that showed the symptoms of xanthomonas wilt, i.e. banana (all cultivars), enset, wild (blood) banana and Canna species (Table 4). Similarly, DNA samples from these symptomatic plant species confirmed the 

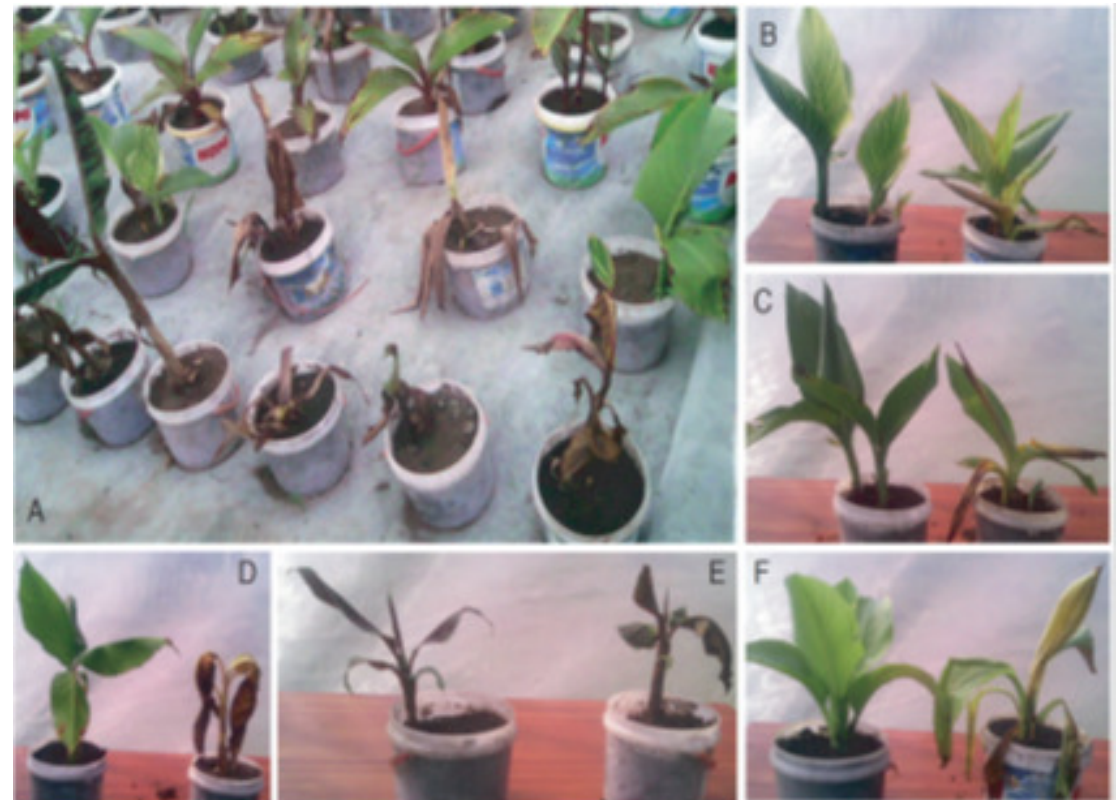

Figure 1. Symptoms of Xcm on banana and banana relatives (A). Control and inoculated Indian shot (B), African arrowroot (C), banana (D), blood banana (E) and enset (F). Achira showed symptoms similar to the other Canna spp.

TABLE 3. Area under disease progress curve (AUDPC) for xanthomonas wilt incidence and severity on banana and other susceptible plant species growing in neighbouring fields in Rwanda

\begin{tabular}{lcc}
\hline Host plant species & \multicolumn{2}{c}{ AUDPC } \\
\cline { 2 - 3 } & Incidence & Severity \\
\hline Achira & 3206 & 1390 \\
African arrowroot & 2800 & 952 \\
Banana & 3962 & 2324 \\
Enset & 3850 & 1918 \\
Indian shot & 3619 & 1453 \\
Wild banana & 3556 & 1607 \\
\hline
\end{tabular}


$\mathbf{a}$

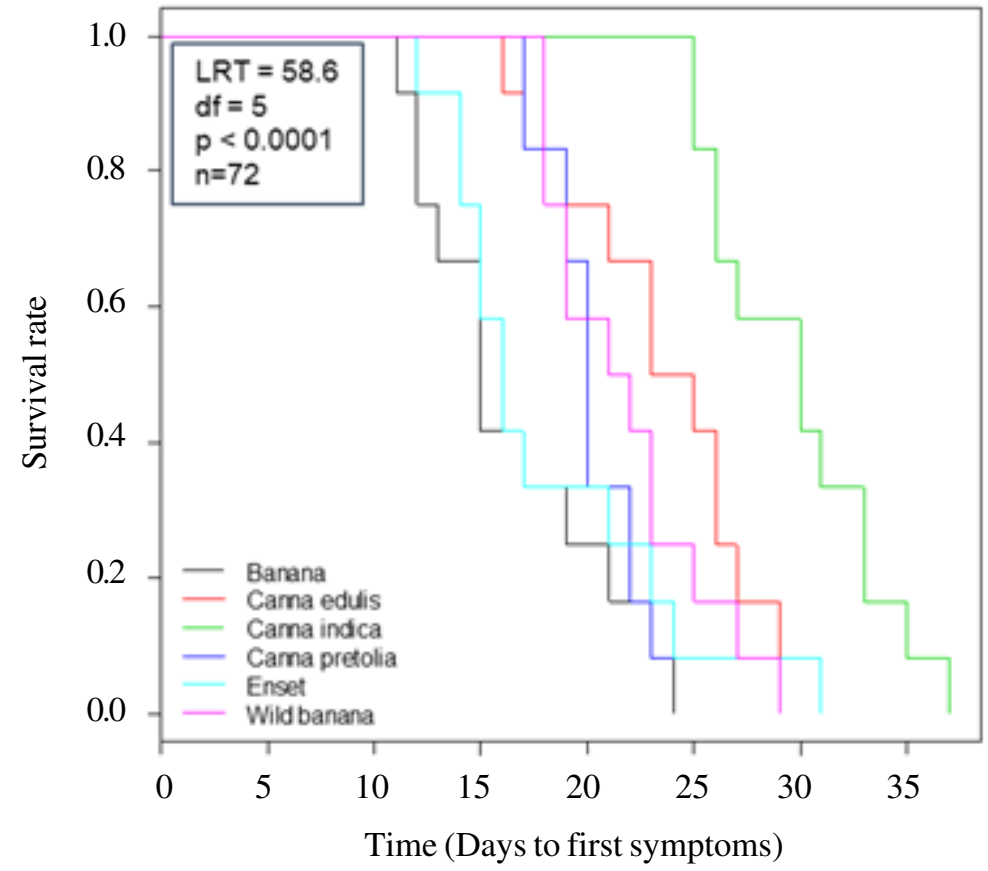

b

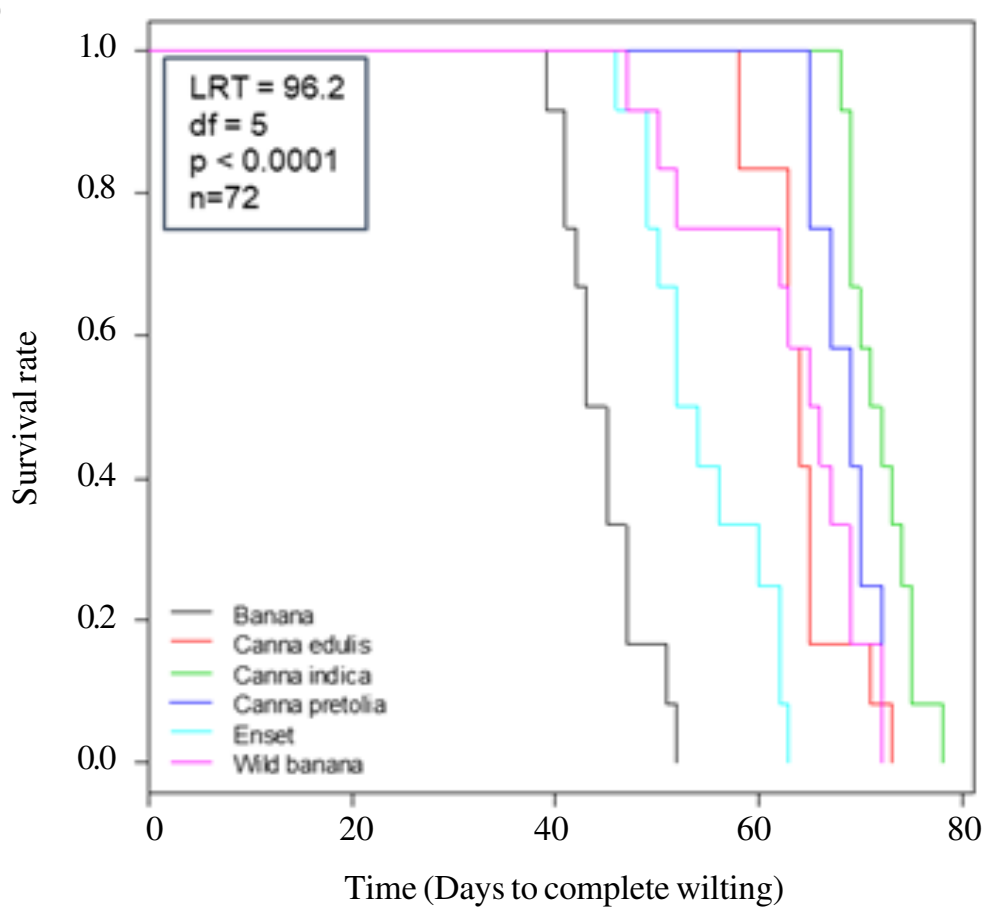

Figure 2. Kaplan-Meier estimates for (a) days to first symptoms expression of susceptible hosts, (b) days to complete wilting of susceptible hosts. $\mathrm{LRT}=$ Likelihood ration test, $\mathrm{df}=$ degree of freedom, $\mathrm{n}=$ total number of observations. 


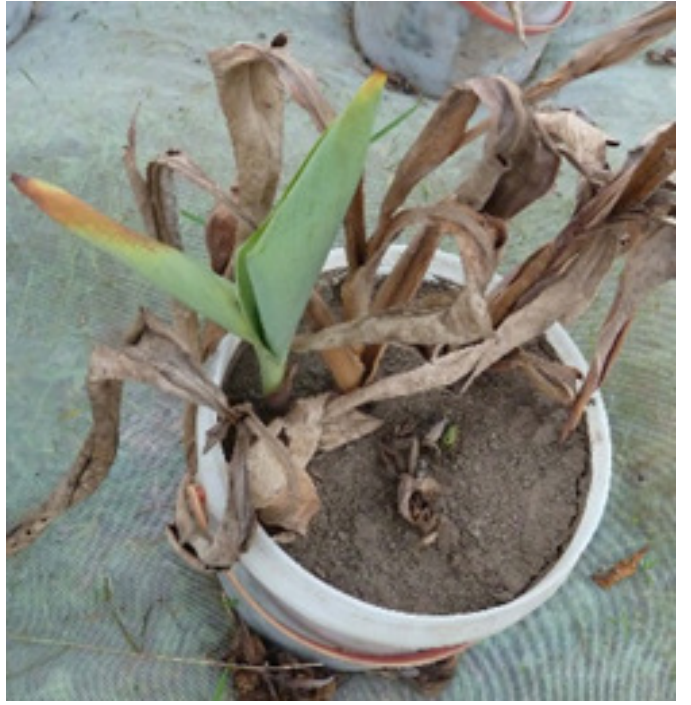

Figure 3. Sprouting Canna spp. after the inoculated mother plant died due to $\mathrm{Xcm}$.

presence of $\mathrm{Xcm}$ using the NZ085, BXW and GspDm markers (Table 4). Despite the absence of symptoms and negative ooze tests, the three markers identified $\mathrm{Xcm}$ in samples collected from groundnuts, maize, pumpkins and sorghum (Table 4). Moreover, positive PCR test with the NZ085 marker confirmed bacterial presence on cassava, beans and wheat (Table 4).

\section{DISCUSSION}

This study has shown that among the crops intercropped with banana, crops in neighbouring fields to banana and banana relatives in Rwanda, Xcm could only infect banana and banana relatives, i.e. wild (blood) banana, enset, African arrow root, achira, and Indian shot (Fig. 1). All the screened cultivars were susceptible to the bacteria, but at slightly different levels. On the other hand, PCR tests identified $\mathrm{Xcm}$ in some plant species that were symptomless in the screen house and tested negative with ooze tests (Table 4).

The bacterium Xcm infected banana, enset, wild banana and Canna spp., which confirm previous findings (Ssekiwoko et al., 2006a; Karamura et al., 2015). However, the isolate of $X \mathrm{~cm}$ used in this study could not infect sorghum and maize, thus, contradicting earlier studies (Aritua et al., 2008; Chala et al., 2016). Several factors like isolate type, host cultivar or different growing conditions may influence the ability of the pathogen to infect the host. It has previously been reported that various isolates of $\mathrm{Xcm}$ reacted differently, while infecting the hosts (Chala et al., 2016).

Our results excluded crops like common beans, sweet pepper, taro, pumpkins, potato, cassava, groundnuts, maize, sorghum, wheats, amaranths and tomato from being host of $X \mathrm{~cm}$. Similarly, Ssekiwoko et al. (2006a) excluded amaranths, tomato, sweet pepper, cassava and some other plants not included in our study from being hosts of $X \mathrm{~cm}$. However, $\mathrm{Xcm}$ detection from symptomless crops (groundnuts, maize, pumpkins and sorghum) by $X \mathrm{~cm}$ specific marker like GspDm, indicate that even if these crops were symptomless, they can harbour the bacterium (Ocimati et al., 2018). Hence, these crops that are often intercropped with banana or grown in neighbouring fields to banana, can contribute to $\mathrm{Xcm}$ dissemination if contaminated.

Our findings agree with previous studies that could not observe the symptoms of $\mathrm{Xcm}$ on maize, but re-isolated the bacteria from inoculated maize, and hence confirmed the ability of maize to harbour the bacteria (Karamura et al., 2015; Ocimati et al., 2018). Marker NZ085 also amplified bacteria in samples from cassava, common beans and wheat. However, these plants should not be considered as potential risk for $\mathrm{Xcm}$ dispersal because NZ085 marker does not only amplify $\mathrm{Xcm}$, but also several other Xanthomonads (Adriko et al., 2012).

The highest values of AUDPC corresponded to the most susceptible host or cultivars, while lower values concurred with less susceptible host or cultivar (Haynes and Weingartner, 2004). We found the highest AUDPC values in banana, followed by enset; whereas the lowest AUDPC was observed in African arrowroot. Similarly, the Kaplan-Meier curves showed that banana plantlets were the 
a

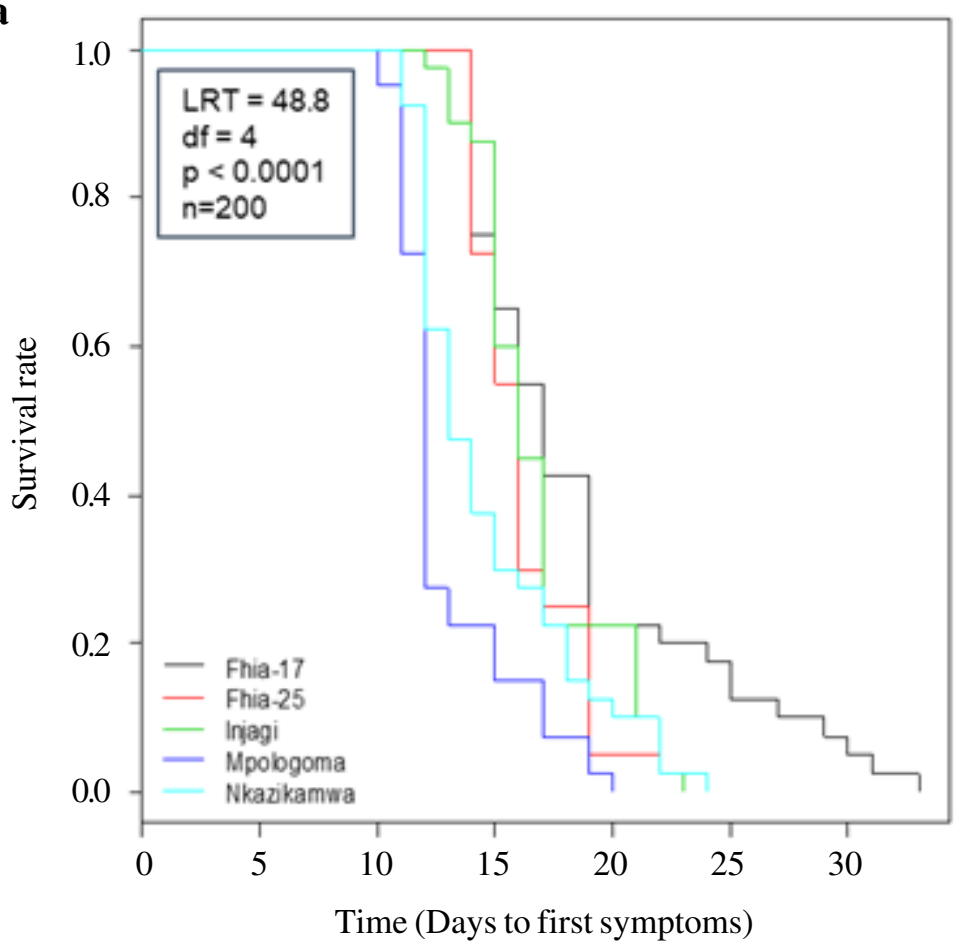

b

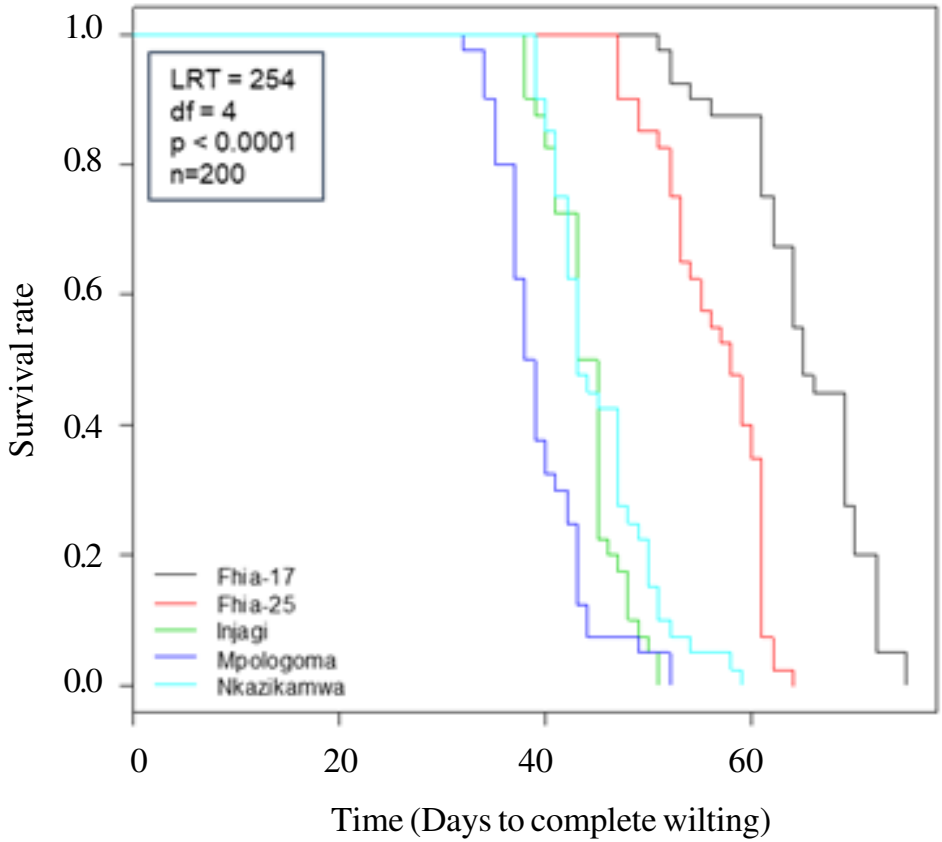

Figure 4. Kaplan-Meier estimates for (a) days to first symptom expression for the tested banana cultivars and (b) days to complete wilting of the banana cultivars. LRT= Likelihood ration test, $\mathrm{df}=$ degree of freedom, $n=$ total number of observations 
TABLE 4. Symptoms, ooze streaming test and PCR test for Xcm recovery from inoculated plant species

\begin{tabular}{lccccc}
\hline Test plants & Symptoms & Ooze test & & \multicolumn{3}{c}{ PCR test } \\
\cline { 3 - 5 } & & BXW & GspDm & \multirow{2}{*}{ NZ085 } \\
& & & &
\end{tabular}

Suspected hosts

\begin{tabular}{|c|c|c|c|c|}
\hline Achira & + & + & + & + \\
\hline African arrowroot & + & + & + & + \\
\hline Amarants & - & - & - & - \\
\hline Cassava & - & - & - & - \\
\hline Beans & - & - & - & - \\
\hline Enset & + & + & + & + \\
\hline Groundnuts & - & - & + & + \\
\hline Indian shot & + & + & + & + \\
\hline Maize & - & - & + & + \\
\hline Potato & - & - & - & - \\
\hline Pumpkin & - & - & + & + \\
\hline Sorghum & - & - & + & + \\
\hline Sweet pepper & - & - & - & - \\
\hline Taro & - & - & - & - \\
\hline Tomato & - & - & - & - \\
\hline Wheat & - & - & - & - \\
\hline Wild banana & + & + & + & + \\
\hline
\end{tabular}

\section{Banana cultivars}

Nkazikamwa

Fhia-17

Mporogoma

Injagi

Fhia-25

+
+
+
+
+

+
+
+
+
+

+
+
+
+
+

$\begin{array}{ll}+ & + \\ + & + \\ + & + \\ + & + \\ + & +\end{array}$

+ observation of symptoms in the greenhouse, bacterial streaming in a glass of water and positive PCR test for Xcm, - no observation of symptoms, bacterial streaming in a glass of water or negative PCR test for $X \mathrm{~cm}$

first to show the symptoms and to wilt completely; while the Canna species were the last. Banana and enset showed the symptoms earlier than other $\mathrm{Xcm}$ host plant species, which could be explained by the fact that they are the initial hosts of the bacteria (Yirgou and Bradbury, 1968; 1974). The finding that Canna spp. express symptoms after banana and enset in this study is in agreement with previous findings (Ssekiwoko et al., 2006a; Chala et al., 2016). In addition, the rhizomes of Canna spp. showed the ability to sprout, while the inoculated mother plant died. The same results have been observed previously (Chala et al., 2016), confirming the inability of $X \mathrm{~cm}$ to colonise the rhizomes of these species. Molecular studies can help to identify if these sprouts do harbour the bacteria latently, and 
TABLE 5. Area under disease progress curve (AUDPC) for xanthomonas wilt incidence and severity on banana cultivars

\begin{tabular}{lcc}
\hline Banana cultivars & \multicolumn{2}{c}{ AUDPC } \\
\cline { 2 - 3 } & Incidence & Severity \\
\hline Fhia-17 & 3801 & 1691 \\
Fhia-25 & 4011 & 1953 \\
Injagi & 3892 & 2562 \\
Mpologoma & 4396 & 2877 \\
Nkazikamwa & 4256 & 2541 \\
\hline
\end{tabular}

hence become sources of new infections. Days to first symptom expression and to complete wilting were significantly longer in wild (blood) banana compared to cultivated banana in this study, which echo earlier findings (Ssekiwoko et al., 2006a).

Our results of screening banana cultivars for susceptibility to $\mathrm{Xcm}$ demonstrate variation in AUDPC (between 3801 and 4396 for disease incidence and between 1691 and 2877 for disease severity) among tested cultivars (Table 5). Correspondingly, the survival times between banana cultivars varied significantly $(\mathrm{P}<0.0001)$, and all cultivars expressed disease symptoms and wilted completely, but at relatively different time points (Fig. 4). Differences in AUDPC and survival times among banana cultivars could be associated to their differences in genetic groups (Tripathi and Tripathi, 2009).

Cultivar Fhia-17, which showed lower AUDPC and longer survival times than other cultivars, belongs to the genetic group AAAA, whereas the highly susceptible cultivar Mpologoma belong to AAA group (Table 2). We found that cultivar Fhia-25 was a bit more susceptible than Fhia-17. According to Tripathi and Tripathi (2009), Fhia-17 belongs to AAAA and Fhia-25 to AABB genetic group. Moreover, Mpologoma, Mbwazirume/Nkazikamwa and Injagi that belong to AAA-EA genetic group were more susceptible than Fhia-17 in this study. Contrary, Tripathi and Tripathi (2009) demonstrated that East African banana cultivars, including Mpologoma and Mbwazirume, were less susceptible compared to Fhia-17. These contradictory findings could be attributed to factors like the inoculum dose, difference in inoculum virulence, age of experimental plants and experimental locations (Ssekiwoko et al., 2006b, Tripathi and Tripathi 2009; Nakato et al., 2018). Previous studies also demonstrated variations in susceptibility to $\mathrm{Xcm}$ between banana cultivars (Ssekiwoko et al., 2006b; Tripathi et al., 2008; Tripathi and Tripathi, 2009). Moreover, the high values of AUDPC in all tested cultivars indicate high susceptibility of cultivated banana cultivars (Haynes and Weingartner, 2004).

The use of host resistance or tolerance to pathogen attack is a key component of plant disease management (Legrève and Duveiller, 2010). It is easy, relatively cheap, environmentally friendly and effective way to limit a plant disease (Dodds and Rathjen, 2010), unless the pathogens overcome the resistance (Juroszek and Von Tiedemann, 2011). We demonstrated longer survival time in some banana relatives and cultivar like Fhia-17. Exploration of the mechanisms involved in the reaction leading to longer survival times in banana relatives and some cultivars, would provide valuable information to breeders when breeding for resistance to $X \mathrm{~cm}$. In addition, it could be considered to avail transgenic banana resistant to $X \mathrm{~cm}$ recently developed in Uganda (Tripathi et al., 2014), which are not yet legally approved for use in any of the countries where BXW is present (Blomme et al., 2017).

In this study, we used a high bacterial concentration $\left(1 \mathrm{ml} * 10^{8} \mathrm{cfu} \mathrm{ml}^{-1}\right)$ compared to other studies and natural conditions (Ssekiwoko et al., 2006a; Ssekiwoko et al., 2006b; Tripathi et al., 2008; Tripathi and Tripathi, 2009). This concentration is considered adequate to confirm that the plants that are not diseased at this concentration are non-hosts to $X \mathrm{~cm}$. Similarly, we could see differences in survival times among susceptible plants and banana cultivars. However, a more 
elaborate field based inoculation method to investigate the susceptibility level of banana cultivars under field conditions, using inoculum entries and quantities similar to normal field infection routes, is necessary.

\section{CONCLUSION}

We confirmed that $X \mathrm{~cm}$ isolates from banana can cause infection in banana relatives viz. wild (blood) banana, enset and Canna species, which are known hosts of $\mathrm{Xcm}$. In addition, we demonstrated the ability of groundnut, maize, pumpkin and sorghum to harbour $\mathrm{Xcm}$, hence, they could potentially act as inoculum source.

The tested cultivars varied in their response to $\mathrm{Xcm}$ infection, which indicates that some levels of tolerance is present in banana cultivars. However, improved inoculation methods are necessary to measure potential tolerance. In case no tolerance can be found, the adoption of transgenic banana cultivars resistant to $\mathrm{Xcm}$ has to be taken into account.

\section{ACKNOWLEDGEMENT}

The funds for this work were provided by the Swedish International Development Cooperation Agency (Sida) through the URSweden Programme for Research, Higher Education and Institutional Advancement.

\section{REFERENCES}

Adriko, J., Aritua, V., Mortensen, C.N., Tushemereirwe, W.K., Kubiriba, J. and Lund, O.S. 2012. Multiplex PCR for specific and robust detection of Xanthomonas campestris pv. musacearum in pure culture and infected plant material. Plant Pathology 61(3):489-497.

Aritua, V., Parkinson, N., Thwaites, R., Heeney, J., Jones, D., Tushemereirwe, W., Crozier, J., Reeder, R., Stead, D.E. and Smith, J. 2008. Characterization of the Xanthomonas sp. causing wilt of enset and banana and its proposed reclassification as a strain of X. vasicola. Plant Pathology 57(1):170-177.

Blomme, G., Dita, M., Jacobsen, K. S., Pérez Vicente, L., Molina, A., Ocimati, W., Poussier, S. and Prior, P. 2017. Bacterial diseases of bananas and enset: Current state of knowledge and integrated approaches toward sustainable management. Frontiers in Plant Science 8:1290. doi: 10.3389/ fpls.2017.01290

Carter, B., Reeder, R., Mgenzi, S., Kinyua, Z., Mbaka, J., Doyle, K., Nakato, V., Mwangi, M., Beed, F., Aritua, V., Lewis Ivey, M.L., Miller, S.A. and Smith J.J. 2010. Identification of Xanthomonas vasicola (formerly X. campestris pv. musacearum), causative organism of banana xanthomonas wilt, in Tanzania, Kenya and Burundi. Plant Pathology 59(2):403-403.

Chala, A., Kebede, T. and Blomme, G. 2016. Natural occurrence and pathogenicity of Xanthomonas bacteria on selected plants. African Journal of Biotechnology 15(39): 2146-2155.

Copes, W.E. and Thomson, J.L. 2008. Survival analysis to determine the length of the incubation period of Camellia twig blight caused by Colletotrichum gloeosporioides. Plant Disease 92:1177-1182.

Crichton, R., Vezina, A. and Van den Bergh, I. 2014. An online checklist of banana cultivars. Acta Horticulturae 1114:13-18. doi: 10.17660/ActaHortic.2016.1114.2

De Mendiburu, F. 2015. Statistical Procedures for Agricultural Research. R package agricolae version 1.5-8. https:/CRAN.Rproject.org/package=agricolae

Diez David, M. 2013. OIsurv: Survival analysis supplement to Open Intro guide. $\mathrm{R}$ package version 0.2. https://CRAN.R-project.org/ package $=$ OIsurv

Dodds, P.N. and Rathjen, J.P. 2010. Plant immunity: tTowards an integrated view of plant-pathogen interactions. Nature Reviews Genetics 11(8):539-548. 
Esker, P.D., Gibb, K.S., Padovan, A., Dixon, P.M. and Nutter Jr., F.W. 2006. Use of survival analysis to determine the postincubation time-to-death of papaya due to yellow crinkle disease in Australia. Plant Disease 90:102-107.

GE Healthcare. 2010. Reliable extraction of DNA from Whatman ${ }^{\mathrm{TM}} \mathrm{FTA}^{\mathrm{TM}}$ cards. GE Healthcare. https://us.vwr.com/assetsvc/ asset/en_US/id/16147319/contents Accessed 23 January 2019.

Haynes, K.G. and Weingartner, D.P. 2004. The use of area under the disease progress curve to assess resistance to late blight in potato germplasm. American Journal of Potato Research 81(2):137-141.

Herigstad, B., Hamilton, M. and Heersink, J. 2001. How to optimize the drop plate method for enumerating bacteria. Journal of Microbiological Methods 44(2):121129.

Horita, M. and Tsuchiya, K. 2001. Genetic diversity of Japanese strains of Ralstonia solanacearum. Phytopathology 91(4):399407.

Juroszek, P. and Von Tiedemann, A. 2011. Potential strategies and future requirements for plant disease management under a changing climate. Plant Pathology 60(1): 100-112.

Karamura, D., Karamura, E. and Tinzaara, W. 2012. Banana cultivar names, synonyms and their usage in Eastern Africa. Bioversity International. Kampala, Uganda. 122pp.

Karamura, G., Smith, J., Studholme, D., Kubiriba, J. and Karamura, E. 2015. Comparative pathogenicity studies of the Xanthomonas vasicola species on maize, sugarcane and banana. African Journal of Plant Science 9(9):385-400.

Legrève, A. and Duveiller, E. 2010. Preventing potential diseases and pest epidemics under a changing climate. In: Raynolds, M.P. 2010. Climate change and crop production. CABI. doi: 10.1079/9781845936334.0000. pp. 50-70.
Lewis Ivey, M.L., Tusiime, G. and Miller, S.A. 2010. A polymerase chain reaction assay for the detection of Xanthomonas campestris pv. musacearum in banana. Plant Disease 94 (1):109-114.

Ocimati, W., Were, E., Groot, J.C., Tittonell, P., Nakato, G.V. and Blomme, G. 2018. Risks posed by intercrops and weeds as alternative hosts to Xanthomonas campestris pv. musacearum in banana fields. Frontiers in Plant Science 9, p.1471. https:/ /doi.org/10.3389/fpls.2018.01471

Madden, L. V., Hughes, G. and Bosch, F. 2007. The study of plant disease epidemics. APS Press. USA. 421pp.

McCampbell, M., Schut, M., Van den Bergh, I., Van Schagen, B., Vanlauwe, B., Blomme, G., Gaidashova S., Njukwe E. and Leeuwis C. 2018. Xanthomonas Wilt of Banana (BXW) in Central Africa: Opportunities, challenges, and pathways for citizen science and ICT-based control and prevention strategies. NJAS Wageningen Journal of Life Sciences doi: 10.1016/ J.NJAS. 2016.2018.03.002

Nakato, V., Mahuku, G. and Coutinho, T. 2018. Xanthomonas campestris pv. musacearum: a major constraint to banana, plantain and enset production in central and east Africa over the past decade. Molecular Plant Pathology 19(3):525-536.

Nakato, G.V., Christelová, P., Were, E., Nyine, M., Coutinho, T.A., Dole•el, J., Uwimana, B., Swennen, R. and Mahuku, G. 2019. Sources of resistance in Musa to Xanthomonas campestris pv. musacearum, the causal agent of banana xanthomonas wilt. Plant Pathology 68(1):49-59.

Nkuba, J., Tinzaara, W., Night, G., Niko, N., Jogo, W., Ndyetabula, I., Mukandala, L., Ndayihanzamaso, P., Niyongere, C., Gaidashova, S., Rwomushana, I., Opio, F. and Karamura, E. 2015. Adverse impact of Banana Xanthomonas Wilt on farmers livelihoods in Eastern and Central Africa. 
African Journal of Plant Science 9(7): 279286.

Nunes Nesi, C., Emiko Shimakura, S., Ribeiro Junior, P.J. and May De Mio, L.L. 2013. Survival analysis in plant pathology. IDESIA (Chile) 31(2):107-110.

Reeder, R., Muhinyuza, J., Opolot, O., Aritua, V., Crozier, J. and Smith, J. 2007. Presence of banana bacterial wilt (Xanthomonas campestris pv. musacearum) in Rwanda. Plant Pathology 56(6):10381038.

Rich, J.T., Neely, J.G., Paniello, R.C., Voelker, C.C., Nussenbaum, B. and Wang, E.W. 2010. A practical guide to understanding Kaplan-Meier curves. Otolaryngology Head Neck Surgery 143(3):331-336.

Setti, B., Bencheikh, M., Henni, J.E. and Claire, N. 2010. Survival analysis to determine the length of latent period of Mycosphaerella pinodes on peas (Pisum sativum L.). African Journal Microbiology Research 4(18):1897-1903.

Ssekiwoko, F., Taligoola, H. and Tushemereirwe, W. 2006a. Xanthomonas campestris pv. musacearum host range in Uganda. African Crop Science Journal 14(2):111-120.

Ssekiwoko, F., Tushemereirwe, W. K., Batte, M., Ragama, P. E. and Kumakech, A. 2006 b. Reaction of banana germplasm to inoculation with Xanthomonas campestris pv. musacearum. African Crop Science Journal 14(2):151-155.

Tinzaara, W., Gold, C., Ssekiwoko, F., Bandyopadhyay, R., Abera, A., and EdenGreen, S. 2006. Role of insects in the transmission of banana bacterial wilt.
African Crop Science Journal 14(2):105110.

Tripathi, L., Mwangi, M., Abele, S., Aritua, V., Tushemereirwe, W.K. and Bandyopadhyay, R. 2009. Xanthomonas wilt: A threat to banana production in East and Central Africa. Plant Disease 93(5): 440-451.

Tripathi, L., Odipio, J., Tripathi, J. N. and Tusiime, G. 2008. A rapid technique for screening banana cultivars for resistance to Xanthomonas wilt. European Journal of Plant Pathology 121(1):9-19.

Tripathi, L. and Tripathi, J. 2009. Relative susceptibility of banana cultivars to Xanthomonas campestris pv. musacearum. African Journal of Biotechnology 8(20):5343-5350.

Tripathi, L., Tripathi, J. N., Kiggundu, A., Korie, S., Shotkoski, F. and Tushemereirwe, W. K. 2014. Field trial of Xanthomonas wilt disease-resistant bananas in East Africa. Nature Biotechnology 32(9):868-870.

Uwamahoro, F., Berlin, A, Bylund, H., Bucagu, C. and Yuen, J. 2018. Potato bacterial wilt in Rwanda: Occurrence, risk factors, farmers' knowledge and attitudes. Food Security 10:1221-1235. Doi: 10.1007/ s12571-018-0834-z

Yirgou, D. and Bradbury, J. 1968. Bacterial wilt of Enset (Ensete ventricosum) incited by Xanthomonas musacearum sp. Phytopathology 58(1):111-112.

Yirgou, D. and Bradbury, J. 1974. A note on wilt of banana caused by the enset wilt organism Xanthomonas musacearum. East African Agricultural and Forestry Journal 40(1):111-114. 